Jurnal Professional FIS UNIVED Vol. 2 No.1 Juni 2015

\title{
PERAN HUMAS DALAM MEMBENTUK CITRA KOTA BENGKULU (Studi pada Humas Pemerintah Kota Bengkulu)
}

Oleh:

\section{INDRIA \\ Dosen Prodi Ilmu Komunikasi Fakultas Ilmu-Ilmu Sosial UNIVED Bengkulu}

\begin{abstract}
Public Relations Department of Bengkulu City assigned to form the image of Bengkulu City Government through a variety of media used. In practice, the PR Department of Bengkulu city has not carry out all the roles and tasks entrusted optimally because of the tendency to deliver the information is still one-way. Several of the barrier factors are: political factor, the existing organizational structure in the Bengkulu City, inadequate infrastructure to support public relations activities, and lack of coordination between the public relation departments that exist in the Provincial and City Government of Bengkulu. While some of the supporting factors of the role and duties implementation are: the funding is sourced directly from Bengkulu City budget in the implementation of public relations activities of the city of Bengkulu, and the motivation to improve the quality and quantity of human resources.
\end{abstract}

\section{Keywords: Public Relation, Image}

\section{PENDAHULUAN}

Humas dalam sebuah organisasi sangatlah penting. Dalam riset tentang kegiatan humas (public relations), ada dua peran besar yang secara konsisten muncul dalam kegiatan humas yaitu peran sebagai teknisi dan manajemen. Peran sebagai teknisi mewakili seni dari humas seperti menulis, mengedit, mengambil foto, menangani produksi komunikasi, membuat event spesial, dan melakukan kontak telepon dengan media. Peran sebagai manajer berfokus pada kegiatan yang membantu organisasi dalam mengidentifikasi dan memecahkan masalah terkait humas.

Manajer humas melaksanakan tiga peran,pertama sebagai pemberi penjelasan, yaitu Pertama orang yang bekerja sebagai konsultan untuk men-definisikan masalah, menyarankan pilihan, dan memantau implementasi kebijakan. Kedua sebagai fasilitator komunikasi, yaitu orang yang berada pada batas antara organisasi dengan lingkungannya yang menjaga agar komunikasi dua arah tetap berlangsung. Ketiga sebagai fasilitator pemecahan masalah, yaitu orang yang bermitra dengan manajer senior untuk mengidentifikasi dan memecahkan masalah (Lattimore,2010).

Fungsi paling dasar humas dalam pemerintahan adalah membantu menjabarkan dan mencapai tujuan program pemerintahan, meningkatkan sikap responsif pemerintah, serta memberi publik informasi yang cukup untuk dapat melakukan pengaturan diri sendiri (Lattimore,2010). Dalam hal ini humas di pemerintahan berperan serta secara aktif menjalankan kegiatan kebijakan dan pelayanan publik dengan memberikan dan memfasilitasi berbagai informasi tentang kebijakan pemerintahan yang baik langsung maupun tidak langsung berhubungan dengan rakyat atau masyarakat. Selanjutnya memberikan pelayanan publik yang terbaik, dengan birokrasi yang tidak berbelit-belit untuk 
memberikan kepuasan kepada rakyat atau masyarakat sehingga dunia pemerintahan memperoleh citra positif dari rakyat atau publik.

\section{PERAN STRATEGIS HUMAS PEMKOT BENGKULU}

Pada dasarnya pimpinan suatu organisasi pemerintahan mempunyai peran yang penting dalam pembentukan citra positif suatu Negara ataupun daerah. Salah satu contohnya yaitu ketika dilaksanakanya kegiatan Forum Konsolidasi Pimpinan Daerah Bupati, Walikota dan Ketua DPRD Kabupaten/Kota tahun 2008 di gedung Lemhannas, terjadi pencitraan negatif bagi pemerintah khususnya pemimpin pemerintah daerah. Di mana sewaktu Presiden Susilo Bambang Yudoyono memberikan pembekalan, terdapat salah seorang kepala daerah yang tertidur. Hal ini menimbulkan kemarahan presiden, "bagaimana bisa memimpin dan memajukan rakyat, bila untuk membicarakan kemajuan rakyatnya tidur" (Tribun, 9/04/08).

Kejadian tersebut telah memperburuk citra pemerintah terutama pemerintah daerah di mata publiknya, karena citra kepala daerah secara tidak langsung akan membentuk citra pemerintahan daerah secara keseluruhan. Dalam melaksanakan perannya, menurut Lattimore (2010) ada empat model humas yang selalu diterapkan. Pertama model Press agentry (agen pemberitaan); yaitu menggambarkan bagaimana informasi bergerak satu arah dari organisasi menuju public, Kedua model informasi publik; yaitu model yang menggambarkan bagaimana humas bertugas memberitahu publik. Model ini selalu dipraktikkan oleh humas pemerintah, lembaga pendidikan, dan organisasi nirlaba. Ketiga, model asimetris dua arah; yaitu memandang humas sebagai kerja persuasi ilmiah yang menggunakan hasil riset untuk mengukur dan menilai publik. Keempat, model simetris dua arah; yaitu sebuah model yang menggambarkan sebuah orientasi humas dimana organisasi dan publik saling menyesuaikan diri. Model ini berfokus pada penggunaan metode riset ilmu sosial untuk memperoleh rasa saling pengertian serta komunikasi dua arah antara publik dan organisasi.

Dari keempat model tersebut, tiga model pertama merefleksikan sebuah praktik humas yang berusaha mencapai tujuan organisasi melalui persuasi. Model keempat berfokus pada usaha menyeimbangkan kepentingan pribadi dengan kepentingan publik atau kelompok lainnya. Dalam sebuah organisasi, khususnya di lingkup pemerintahan, humas memegang peranan yang sangat penting dan strategis. Selain itu, sebagai sebuah kegiatan komunikasi, humas juga berfungsi sebagai jembatan untuk membangun suasana yang kondusif dalam kerangka 'win-win solutions', antar berbagai stakeholders organisasi, baik internal maupun eksternal dalam rangka membangun citra dari instutusi pemerintah itu sendiri.

Oleh karena itu praktik humas yang paling ideal di dunia pemerintahan adalah berdasarkan model simetris dua arah. Peranan Humas pemerintah adalah untuk memberikan sanggahan mengenai pemberitaan yang salah dan merugikan pemerintah, dan mengkomunikasikan atau menginformasikan berbagai kebijakan pemerintah kepada masyarakat. Hal ini bertujuan untuk membentuk citra positif pemerintah daerah tersebut dimata publiknya. Pentingnya peran Humas instansi dan lembaga perintah dalam masyarakat modern yaitu dalam melakukan kegiatankegiatan dan operasinya di berbagai tempat berbagai bidang. Teknik yang digunakan dalam humas di perintah tidak ada bedanya dengan teknik yang digunakan humas di 
bidang lain yaitu penyampaian informasi dan komunikasi (Moore, 2004).

Demikian juga halnya dengan Pemerintah Kota Bengkulu, yang saat ini menjadi pemberitaan publik atas kasus korupsi dana bantuan sosial yang melibatkan kepala daerah sebagai tersangka. Kasus ini menjadi sorotan publik dan membuat buruknya citra pemerintah kota Bengkulu. Gencarnya pemberitaan mengenai kasus korupsi di lingkungan pemerintah kota Bengkulu membuat kepercayaan publik terhadap pemeritah semakin menurun. Pemerintah Kota Bengkulu pernah pula mendapat sorotan publik, baik secara lokal maupun nasional terhadap program shalat berjamaah dengan hadiah kendaraan roda empat. Kebijakan ini mendapatkan kecaman sebagian besar masyarakat. Masyarakat menganggap program ini tidak layak dan terkesan menghambur-hamburkan uang. Selain itu secara kultur, masyarakat menganggap bahwa program tersebut tidak sesuai dengan adat istiadat masyarakat lokal.

Tercorengnya citra pemerintah kota Bengkulu mengakibatkan berbagai hal. Kebijakan-kebijakan Pemerintah Kota Bengkulu dianggap terkesan tidak memperdulikan kekecewaan masyarakat terbelakang dan kurang sejahtera yang sebagian besar masih ada di Kota Bengkulu. Sebagian masyarakat berpendapat "dari pada pemerintah mengadakan seremonial dan menjadi tuan rumah pada acara-acara bertaraf nasional lebih baik pemerintah lebih mengutamakan kelangsungan hidup masyarakat kecil”. Akan tetapi sebagian masyarakat yang lain beranggapan event tersebut dapat mempublikasikan Bengkulu di tingkat nasional (Intan, 2015).

Penyampaian informasi berupa program dan kebijakan Pemerintah Kota Bengkulu juga melalui Humas menggunakan media berupa pidato, media luar ruang berupa baliho, dan website.
Humas Kota Bengkulu menjalin hubungan dan kerja sama dengan beberapa media massa, baik media massa nasional maupun lokal. Hal ini dilakukan untuk mempermudah wartawan meliput mengenai kegiatan-kegiatan Pemerintah Kota Bengkulu terutama kegiatan yang dilaksanakan oleh Walikota Bengkulu.

Peran yang dilaksanakan oleh Humas Kota Bengkulu yang tercermin dalam aktivitasnya cenderung membentuk citra positif Walikota Bengkulu dibandingkan dengan citra Pemerintah Kota Bengkulu secara keseluruhan. Aktivitas yang dilaksanakan oleh Humas Daerah Kota Bengkulu seperti peliputan dan pempublikasian informasi lebih fokus pada kegiatan yang dilaksanakan oleh Walikota. Pola ini sangat terlihat pada kegiatan humas pada akhir periode pemerintahan pertama. Begitu juga dengan website humas dan baliho yang dibuat humas selalu mempublikasikan kegiatan walikota. Dapat dikatakan adanya suatu ketidak-seimbangan antara aktivitas Humas Kota Bengkulu untuk membentuk citra positif Pemerintah Kota Bengkulu secara keseluruhan atau untuk membentuk citra positif Walikota Bengkulu.

\section{USAHA CITRA POSITIF ATAU NEGATIF}

Berdasarkan fenomena tersebut yang menjadi permasalahan adalah bagaimana peran Humas Kota Bengkulu dalam menginformasikan berbagai kebijakan pemerintah kepada masyarakat untuk membentuk citra positif pemerintah daerah. Humas dibentuk di lembaga pemerintah diantaranya sebagai juru bicara pemerintah, melakukan hubungan timbal balik antara pemerintah daerah dengan masyarakat umum dan organisasi kemasyarakatan untuk memperjelas kebijakan dan kegiatan pemerintah daerah, melakukan hubungan 
intern dengan satuan dan unit kerja di lingkungan pemerintah, melaksanakan usaha untuk peningkatan peliputan kegiatankegiatan yang dilaksanakan oleh pemerintah maupun masyarakat dan melaksanakan koordinasi/kerja sama dengan organisasi kewartawanan (Moore, 2004).

Dengan pelaksanaan peran humas pemerintah, tujuan akhirnya adalah untuk membentuk citra yang positif tentang pemerintah di mata masyarakatnya. Citra mencerminkan apa yang dipikirkan, emosi dan persepsi individu. Walaupun orang melihat hal yang sama, tapi pandangan mereka bisa berbeda. Persepsi inilah yang membentuk citra dari sebuah organisasi (Alifahmi, 2005). Esensi tujuan humas di dunia pemerintahan adalah membuat berbagai program pemerintah yang dapat membentuk, meningkatkan dan memelihara citra positif dan reputasi baik agar dapat memperoleh opini publik yang menguntungkan, serta dukungan dan simpati rakyat atau publik.

Citra sengaja diciptakan Humas dalam dunia pemerintahan dalam bentuk events (kegiatan-kegiatan), kampanye dan program-program (Nanda, 2015). Tujuan penelitian ini adalah untuk mengetahui secara menyeluruh dan mendalam mengenai peran Humas Kota Bengkulu dan faktorfaktor penghambat dan pendukung aktivitas Humas Kota Bengkulu dalam membentuk citra positif Pemerintah Kota Bengkulu. Humas merupakan fungsi manajemen dalam sebuah organsiasi yang berperan untuk membangun kesepahaman antara organisasi dan publiknya (Berg, 2011). Berdasarkan peran yang dimilikinya, humas sebenarnya lebih merupakan aktivitas mengelola arus pesan/komunikasi yang terjadi di institusinya. Manakala pesan itu dapat menjadi lifeblood di institusinya, maka upaya untuk membangun understanding, goodwill dan image (citra) dengan para stakeholder serta merta akan mudah dicapai (Sinatra, 2008).

Tugas dan Fungsi pokok humas pemerintahan tidak lepas dari pembentukan citra. Demikian juga dengan Humas Kota Bengkulu, di mana aktivitas yang dilaksanakan oleh Humas Kota Bengkulu tidak lepas dari usaha pembentukan citra Pemerintah Kota Bengkulu di mata masyarakat. Citra positif merupakan tujuan utama yang harus dicapai oleh Pemerintah Kota Bengkulu, terutama oleh Walikota yang mana akan menentukan kelangsungan kekuasaan yang dimiliki atau disebut dengan performed image, yaitu lebih ditujukan pada subjeknya, bagaimana penampilan diri para pimpinan pemerintahan yang kemudian secara tidak langsung akan membentuk citra pemerintahan itu secara keseluruhan (corporate image).

Citra adalah kesan, perasaan, gambaran diri publik terhadap perusahaan. Kesan ini diciptakan secara sengaja dari suatu obyek, orang atau organisasi. Jadi citra itu dengan sengaja perlu diciptakan agar bernilai positif. Citra itu sendiri merupakan salah satu asset terpenting dari suatu perusahaan atau organisasi, atau dalam istilah lain disebut favourable Opinion (Sumirat \& Ardianto, 2005). Citra Pemerintah Kota Bengkulu saat ini ada yang beranggapan positif dan ada yang beranggapan negatif. Ada yang beranggapan Pemerintah Kota Bengkulu hanya menghambur-hamburkan uang sedangkan masyarakat Bengkulu masih miskin. Sebagian masyarakat ada yang beranggapan positif mengenai kinerja Pemerintah Kota Bengkulu saat ini karena dapat memajukan budaya lokal.

Citra Pemerintah Kota Bengkulu tercipta dari pandangan masyarakat terhadap kinerja Pemerintah Kota Bengkulu dan juga hasil dari penciptaan melalui penggunaan media dan saluran komunikasi. Citra 
Pemerintah Kota Bengkulu terbentuk juga melalui kegiatan-kegiatan pemerintah dan kegiatan kehumasan yang telah dilaksanakan Pemerintah Kota Bengkulu yang ditujukan kepada masyarakat. Menurut Arifin (2009) dalam penyebaran informasi tentang kegiatan pemerintah kepada masyarakat di Bengkulu.

\section{PRODUK HUMAS DALAM MEMBANGUN CITRA KOTA BENGKULU}

Humas sangatlah berperan penting, dimana sebesar 51,61\% informasi yang diterima masyarakat tentang pemerintah berasal dari humas. Di sinilah peran penting dari humas dalam penyebaran informasi mengenai program dan hasil pembangunan Pemerintah Kota Bengkulu sehingga dapat membentuk citra positif dari Pemerintah. Dalam melaksanakan perannya Humas Pemerintah Kota Bengkulu sebenarnya melakukan komunikasi yang berlangsung dua arah. Humas menyampaikan kebijakan dan program Pemerintah Kota Bengkulu menggunakan saluran komunikasi berupa media massa, baik media luar ruang berupa baliho dan poster, pidato dan presentasi pimpinan, website, publikasi khusus maupun dengan hubungan dengan media massa lainnya.

Humas juga melakukan upaya komunikasi untuk mendapatkan respon dari masyarakat terhadap Pemerintah Kota Bengkulu. Humas Kota Bengkulu kadangkala melaksanakan evaluasi kerja berdasarkan berita-berita dan umpan balik yang terdapat pada media massa, kemudian hasil evaluasi tersebut disampaikan kepada pimpinan yang menjadi umpan balik terhadap kebijakan dan program yang telah dikeluarkan Pemerintah kota Bengkulu. Namun dalam pelaksanaannya informasi yang menjadi masukan bagi pemipnan pemerintahan yang dalam hal ini kota tidaklah direspon secara maksimal.

Aktivitas Humas Pemerintah Kota Bengkulu dalam membentuk citra positif Pemerintah Kota Bengkulu memang terlihat masih belum optimal. Sebagian besar masyarakat masih menganggap citra Pemerintah Kota Bengkulu belum begitu baik atau malah ada kecenderungan memiliki citra yang negatif. Hal ini disebabkan aktivitas Humas Kota Bengkulu dalam membentuk citra positif pemerintah Kota Bengkulu hanya baik dalam citra di media massa atau pers saja. Namun sebaliknya informasi pembangunan Kota Bengkulu yang didapatkan langsung oleh masyarakat dalam kenyataanya masih jauh dari harapan. Menurut Arifin (2009) Humas selalu mengundang wartawan (84\%) sebagai cara untuk menyampaikan formasi daripada melakukan dialog interaktif kepada elemen masyarakat (8\%).

Dari hasil riset ini terlihat bahwa komunikasi yang dilakukan Pemerintah Kota Bengkulu kepada masyarakatnya cenderung searah, karena lebih banyak menggunakan media massa. Sementara evaluasi kinerja dan riset tentang opini masyarakat tentang pemerintah juga tidaklah menjadi perhatian serius dari humas, sehingga apa yang menjadi persepsi masyarakat tentang pemerintah tidaklah dipahami dengan baik. Hal ini tentu saja citra positif yang ingin dibentuk oleh Pemerintah Kota Bengkulu tidaklah optimal. Sehingga masih banyak pandanganpandangan negative masyarakat terhadap pemerintah terus berlangsung.Temuan ini mendukung teori Lattimore (2010) bahwa kegagalan peran humas dalam membentuk citra positif pemerintahan disebabkan peranan humas dalam menyebar-luaskan informasi tentang kegiatan pemerintahan tidak berdasarkan model komunikasi simetris dua arah. Selaku 'corong', 
pemerintah, bagian humas hendaknya tidak hanya bertugas mengkliping berita atau mengoordinasi para jurnalis untuk ikut kunjungan rombongan presiden atau kepala daerah ke lapangan. Tapi, bagaimana mereka juga bisa mengarahkan sekaligus menyiapkan materi berita yang layak untuk konsumsi publik. Sebab, tidak semua agenda kegiatan dan program pemerintah memiliki nilai jual bagi media. Tapi, kalau program atau kegiatan pemerintahan itu dianggap memiliki momen dan nilai penting menurut kacamata pemerintah, tentu bisa dilakukan dengan cara memasang advertorial (iklan berita) di media.

Hal ini juga bisa dilakukan oleh institusi lain di internal pemerintahan seperti kantor kementerian, biro,dinas, bagian, dan lain sebagainya. Salah satu tujuannya, agar masyarakat tahu apa saja program yang telah direalisasikan oleh pemerintah untuk masyarakatnya atau warganya. Mengharapkan media sebagai corong pemerintah dalam membentuk citranya, akan memperkecil kemampuan pemerintah (negara) dalam mengembangkan kepentingan sendiri, sehingga senantiasa hanya dianggap sebagai representasi pergulatan kepentingan dalam masyarakat.

Produk media hanyalah rekaman atas pola relasi dinamis antara Negara dan kekuatan-keuatan dalam masyarakat (Abdul Firman Ashaf, 2006). Konsep citra seperti yang dikemukakan Hifni Alifahmi (2005) merupakan persepsi yang membentuk citra suatu organisasi. Dengan demikian, apabila peran Humas Kota Bengkulu dalam membentuk citra pemerintah yang hanya mengandalkan media massa, maka eksistensi Humas dalam menyebarluaskan informasi mengenai pembangunan di Kota Bengkulu dianggap tidak mempunyai peranan yang berarti dalam menampung aspirasi masyarakat, sehingga lama kelamaan timbul rasa ketidakpercayaan masyarakat pada pemerintah (public trust).

Hal senada juga diungkapkan oleh Silalahi (2011) tentang pelayanan birokrasi Pemerintah Kota Bandung dalam perizinan usaha, dimana tidak sebandingnya antara harapan masyarakat dengan kinerja actual pelayanan birokrasi terhadap izin usaha, dimana birokrat tidak memihak kepada kepentingan masyarakat ketika memberikan pelayanan publik, yang akhirnya tidak dipercaya lagi oleh publik. Oleh karena itu seorang humas haruslah memahami betul apa yang dibutuhkan dan kepentingan masyarakat.. Untuk itu humas haruslah secara aktif menyerap informasi yang ada dari masyarakat. Seperti yang ada pada model humas simetris dua arah humas pemerintah dan masyarakat dapat saling menyesuaikan diri dengan terciptanya saling pengertian serta komunikasi dua arah antara pemerintah dengan masyarakat. Jika humas hanya mengandalkan media massa dalam melaksakan fungsinya tentu saja menyebabkan fungsi tersebut tidak terlaksana dengan optimal.

Humas haruslah memahami apa yang terjadi di masyarakat dengan memanfaatkan secara optimal informasi dari kliping berita di media, menganalisisnya serta menginformasikannya kepada kepala pemerintahan dalam hal ini adalah Walikota Bengkulu. Pelaksanaan kegiatan pada Humas Pemerintah Kota Bengkulu ini juga mengalami beberapa hambatan:

a. Kedudukan Humas pada Pemerintahan Kota Bengkulu sangat mem-batasi aktivitas dan ruang gerak Humas. Banyak kegiatan yang dilakukan hanya didasarkan pada struktur dan peraturan yang ada, sehingga sulit untuk lebih kreatif dalam mengembangkan kegiatan yang dilakukan; 
b. Kurang memadainya infrastruktur dan sarana pendukung kegiatan kehumasan;

c. Kurangnya koordinasi yang terjadi diantara humas yang ada di dinas, badan,kabupaten dan kota dengan humas provinsi.Sehingga menyebabkan kurangnya pertukaran informasi dari tiap-tiap instansi yang ada di Kota Bengkulu, yang menyebabkan kurangnya informasi dan komunikasi yang terjadi pada humas yang ada pada Pemerintah Kota Bengkulu;

d. Adanya faktor-faktor kebijakan yang bersifat politis, sangat menghambat aktivitas humas dalam pembentukan citra, dimana terbatasnya ruang lingkup aktivitas humas dikarenakann adanya kecenderungan kepala daerah untuk selalu menjadi sorotan media, dimana adanya keinginan dari Walikota yang menjabat untuk mendapatkan jabatan kembali.

Namun di sisi lainnya, ada beberapa faktor pendukung peran kehumasan di Pemeritahan Kota Bengkulu dalam membentuk citra positif Pemerintah Kota Bengkulu. Faktor tersebut diantaranya adalah Organisasi Humas Pemerintah Kota Bengkulu merupakan organisasi yang langsung berada di bawah Sekretaris Daerah Kota Bengkulu, sehingga Humas Kota Bengkulu tidak bermasalah dengan anggaran yang dibutuhkan.Sekretariat Daerah Kota Bengkulu merupakan organisasi pemerintahan yang membawahi dinas-dinas dan badan yang ada di Kota Bengkulu.

Oleh karena itu, dinas-dinas dan badan yang ada di Kota Bengkulu dapat melakukan koordinasi dengan Sekretariat Daerah Kota Bengkulu dalam membuat kebijakan atau program dengan lebih baik. Hal tersebut tentunya dapat memudahkan
Bagian Humas Pemerintah Kota Bengkulu untuk berkoordinasi dengan dinas dan badan yang ada di Provinsi Bengkulu dengan mencitrakan kebijakan sesuai dengan bidangnya masing- masing, tetapi dalam pelaksanaannya peluang ini tidak dimanfaatkan secara optimal.

\section{PENUTUP}

\section{Kesimpulan}

Peran humas pemerintah Kota Bengkulu dalam membentuk citra positif Pemerintah Kota Bengkulu dilaksanakan secara tidak langsung atau berada di balik layar, karena Humas Pemerintah Kota Bengkulu memberikan informasi-informasi mengenai pembangunan Kota Bengkulu cenderung satu arah melalui media massa. Hal ini menyebabkan citra positif yang ingin dibentuk oleh Humas Pemerintah Kota Bengkulu belum dapat terlaksana secara optimal, sehingga eksistensi Humas di mata publik sebagai lembaga pemerintah dalam menyebarluaskan informasi mengenai pembangunan tidak representatif dalam menampung aspirasi masyarakat.

Media yang digunakan oleh Humas Kota Bengkulu antara lain: media massa (pers), media luar ruang (baliho dan poster), pidato dan presentasi yang dibacakan pimpinan, website humas yaitu wwwbengkulukota.go.id, publikasi khusus berupa buku saku Info Bengkulu, suratmenyurat langsung yang disebarkan kepada instansi atau lembaga terkait, dan acaraacara khusus seperti Forum Koordinasi Kehumasan dan kegiatan wisata pers (press tour).

Faktor penghambat Humas Kota Bengkulu dalam pembentukan citra positif Pemerintah Kota Bengkulu antara lain faktor sumber daya manusia, kemudian faktor politis, struktur organisasi yang ada di Pemerintah kota Bengkulu yang menyebabkan keterbatasan wewenang 
sehingga menghambat kinerja humas yang optimal dan profesional, kurang memadainya infrastruktur, dan kurangnya koordinasi antara Humas Kota Bengkulu dengan humas-humas yang ada di lingkungan Pemerintah Kota Bengkulu. Faktor pendukung aktivitas dalam pembentukan citra positif Pemerintah Kota Bengkulu adalah Humas Kota Bengkulu mendapat dana langsung dari APBD Kota Bengkulu, kemudian adanya motivasi untuk meningkatkan sumber daya manusia baik di bidang pendidikan, keahlian, kualitas dan kuantitas dari pegawai Humas Kota Bengkulu.

\section{DAFTAR PUSTAKA}

Abdul Firman Ashaf. (2006). "Pola Relasi Media, Negara dan Masyarakat: Teori Strukturisasi Anthony Giddens sebagai Alternatif”.

Berg, K. T. \& Gibson, K. (2011). Hired guns and moral torpedoes: Balancing the competing moral duties of the public relations professional.

Moore, Frazier. (2004). "Humas: Membangun Citra dengan Komunikasi”. Bandung: Remaja Rosdakarya.

Hifni Alifahmi. (2005). "Sinergi Integrasi Iklan, Komunikasi, Public
Relations, pemasaran dan Promosi”. Bandung: Mizan Media Utama.

Soleh Soemirat \& Elvinardo Ardianto. (2003). "Dasar-Dasar Public Relations”. Bandung: Remaja Rosdakarya.

Silalahi, Uber. (2011). “Kepercayaan Publik kepada Pemerintah Daerah Pasca Orde Baru”.

Lattimore. (2010). "Public Relations, Profesi dan Praktik”. Jakarta: Salemba Humanika.

Arifin, Ali Murtadha M, (2006). Sistem Informasi Pemerintahan pada Otonomi Daerah di Pemerintahan Kota Pekanbaru, Jurnal Penelitian Komunikasi dan Pembangunan.

Jurnal JIANA, Sinatra, Lina dan Rini Darmastuti. (2008). "Kajian Peran Public Relations Dalam Meningkatkan Citra Perguruan Tinggi Swasta di Jawa Tengah”.

Tribun Pekanbaru, Faisal Bahri. (2008). "Pemerintah Provinsi Bengkulu Kikir".

APDB,www.Bengkuluinfo.com tanggal akses 25/05/08

Opini, $\quad w w w . B e n g k u l u i n f o . c o m, \quad$ tanggal akses25/05/08. 